\title{
REVIEW ARTIKEL: FORMULASI DAUN JERUK PURUT DAN SERAI SEBAGAI TABLET ANTIFEEDANT
}

\author{
Abdul David Pongsapan ${ }^{1)^{*}}$ Annisa Khoirotun Hisan ${ }^{1)}$ Deshanda Kurniawan Prayoga ${ }^{1)}$ Salfa \\ Efata Glory Rambi ${ }^{1)}$ Hosea Jaya Edy ${ }^{1)}$ \\ ${ }^{1}$ Program Studi Farmasi, Fakultas Matematika dan Ilmu Pengetahuan Alam, Universitas Sam Ratulangi, \\ Manado, Indonesia \\ *Penulis Korespondensi: nandel.afah.rito05@gmail.com
}

\begin{abstract}
Rice stored in warehouses is susceptible to pests such as rice lice (Sitophilus oryzae) familia Curculionidae which crushes rice grains and reduces rice quality. As a vegetable insecticide with an antifeedant effect, the essential oils found in lime leaves and lemongrass contain citronellol and citronella which are capable of repelling insects. Citrus leaf antifeedant can repel subterranean termites (Coptotermes sp.) with the highest levels at concentrations of $20 \%$ and $25 \%$ in the test time of less than 5 days. While lemongrass is able to control several pests, including Helicoverpa armigera, Plutella xylostella, Aedes mosquitoes (Anopheles and Culex), Dasynus piperis (pepper sucking pest), Helopeltis antonii (cocoa pod sucking pest), Noorda albizonalis (mango fruit borer), fruit flies, and mealybugs on papaya leaves. Citrus leaves and lemongrass are combined in tablets. The concentration of kaffir lime leaf essential oil made at $4 \mathrm{ml} / \mathrm{g}, 8 \mathrm{ml} / \mathrm{g}, 12 \mathrm{ml} / \mathrm{g}$, and $16 \mathrm{ml} / \mathrm{g}$ significantly affected the amount of $S$. oryzae present. The highest concentration resulted in fewer S. oryzae imago. The Index lasts on a 3hour timeframe. The Repellent Index decreased after 24 hours.
\end{abstract}

Keywords: Sitophilus oryzae, leam leaves, lemongrass, antifeedant, essential oil, repellent

\begin{abstract}
ABSTRAK
Penyimpanan padi didalam gudang rentan terhadap serangan hama seperti kutu beras (Sitophilus oryzae) yang menyebabkan kualitas beras buruk karena remuknya butiran beras. Sebagai insektisida nabati yang berefek antifeedant, minyak atsiri yang terdapat pada daun jeruk serta serai memiliki kandungan sitronellol dan citronella yang bersifat repellent terhadap serangga. Aktifitas antifeedant daun jeruk dapat menolak rayap tanah (Coptotermes sp.) paling tinggi pada konsentrasi $20 \%$ dan $25 \%$ dalam waktu uji selama kurang dari 5 hari. Serai mampu mengendalikan beberapa hama, diantaranya Helicoverpa armigera, Plutella xylostella, nyamuk Aedes (Anopheles dan Culex), Dasynus piperis (hama penghisap buah lada), Helopeltis antonii (hama penghisap buah kakao), Noorda albizonalis (hama penggerek buah mangga), lalat buah, dan kutu putih pada daun papaya. Perpaduan daun jeruk dan serai dibuat dalam sediaan tablet yang berfungsi sebagai antifeedant kutu beras karena mengandung senyawa citronella dan geraniol. Konsentrasi minyak atsiri daun jeruk purut dibuat $4 \mathrm{ml} / \mathrm{g}, 8 \mathrm{ml} / \mathrm{g}, 12 \mathrm{ml} / \mathrm{g}$, dan $16 \mathrm{ml} / \mathrm{g}$ yang berpengaruh nyata terhadap mortalitas $S$. oryzae. Indeks Repellent bertahan pada rentang waktu 3 jam dan setelah waktu 24 jam, Indeks Repellent menurun.

Kata kunci: Sitophilus oryzae, daun jeruk, serai, antifeedant, minyak atsiri, repellent
\end{abstract}




\section{Pendahuluan}

Indonesia merupakan negara pengonsumsi beras terbesar di dunia. Indonesia mengalami peningkatan dalam memproduksi padi pada tahun 2020 (Baheramsyah, 2021), Berdasarkan Data (Badan Pusat Statistik, 2020), luas panen di Indonesia pada tahun 2019 sebesar 10,66 juta hektar denga hasil panen sebesar 54.65 juta ton. Jika dikonversikan menjadi beras, maka untuk jumlah produksi beras pada tahun 2019 mencapai 31,33 juta ton. Padi yang diproduksi dalam jumlah yang besar akan disimpan di dalam gudang sehingga memungkinkan resiko untuk mendapatkan gangguan dari hama.

Kutu beras (S. oryzae) yang termasuk dalam familia Curculionidae dari genus Sitophilus merupakan salah satu hama pengganggu hasil panen. Dampak dari beras yang terkena serangan hama ini adalah remuknya butiran beras menjadi seperti tepung, sehingga kualitasnya menurun (Sakul et al., 2012).

Pestisida berbahan kimia umumnya digunakan untuk pengendalian hama kutu beras ( $S$. oryzae). Pencemaran lingkungan dan menurunnya mutu suatu produk merupakan contoh dampak negatif dari penggunaan pestisida berbahan kimia. Untuk meminimalisir hal-hal tersebut dibutuhkan pengganti pestisida kimia dengan pestisida nabati yang terbuat dari tumbuhan (Soenandar, Aeni dan Raharjo, 2010).

\section{Jeruk Purut (Citrus hystryx)} merupakan tanaman yang banyak terdapat di Indonesia. Minyak atsiri daun jeruk purut dapat digunakan sebagai pestisida nabati. Senyawa sitronellol dalam minyak atsiri termasuk senyawa yang bersifat repellent terhadap serangga (Santya and Hendri, 2013). Tanaman serai (Cymbopogon nardus) memiliki kandungan minyak atsiri yang terdiri atas sitral, sitronela, geraniol, mirsena, nerol, farnesol, metil haptenol dan dipentena. Kandungan minyak atsiri bekerja secara racun kontak dan racun sistemik (Lestari, 2020)

\section{Metode Penelitian}

Metode yang digunakan yaitu review artikel atau studi pustaka yang diawali dengan penelusuran artikel/jurnal publikasi pada Google Scholar, Researchgate, Elsevier dan sumber penelusuran lainnya. Penyusunan review artikel berdasarkan hasil penelitian yang berasal dari jurnal maupun artikel ilmiah dengan tetapan tahun terbit jurnal sepuluh tahun terakhir diberbagai jenis database baik luar maupun dalam negeri. Sedangkan informasi terkait data diakses melalui laman bps.go.id. Pencarian jurnal dilakukan melalui google menggunakan kata kunci; Sitophilus oryzae, daun jeruk, serai, antifeedant, minyak atsiri, repellent. Data yang didapat kemudian dikumpulkan, diolah lalu diinterpretasi dengan baik sesuai dengan judul PKM yang akan dilakukan sehingga terbentuk suatu review artikel yang dapat memberikan informasi tentang formulasi daun jeruk purut dan serai dalam bentuk tablet yang terdapat kandungan antifeedant untuk mengatasi permasalahan beras akibat kutu beras.

\section{Hasil dan Pembahasan}

\section{Kandungan Kimia daun jeruk purut dan serai serta pemanfaatannya}

Hasil uji fitokimia ekstrak alkohol 96\% daun jeruk perut positif mengandung alkaloid, flavonoid dan monoterpenoin serta sesquiterpenoid sebagai penyusun minyak atsiri (Hanina and Baringbing, 2020). Flavonoid berfungsi mengganggu respirasi dan menyebabkan penurunan fungsi oksigen menyebabkan segala gangguan saraf dan gangguan spirakel yang berakhir pada kematian pada serangga (Ginting, 2012), alkaloid menghambat sintesis protein sel (Putri, 2017), monoterpenoin serta sesquiterpenoid penyusun minyak atsiri yang menghalangi proses difusi masuknya oksigen kedalam tubuh.

Penetapan kadar flavonoid total pada ekstrak daun jeruk purut dilakuakan dengan menggunakan spektrofotometer UV-Vis. Diperoleh Panjang gelombang maksimum kuersetin yaaitu $510 \mathrm{~nm}$, dengan hasil kadar flavonoid total ekstrak daun jeruk sebesar 0,687\% b/b (Yanuarty, 2021). 
Hasil skrining senyawa daun jeruk purut dengan menggunakan metode Gas Chromatography-Mass Spectroscopy (GCMS), dilaporkan mengandung kandungan minyak atsiri daun jeruk purut yang berupa citronella, Beta-sitronellol, Linalool L., 2,6-oktadiene, 6-7-Epoksi-3,7dimetilkotanal, dan (-)-isopulegol (Lestari, Jayuska and Indrayani, 2015).

Daun serai sangat banyak mengandung senyawa kimia yang berguna untuk tanaman itu sendiri dan sebagai bahan zat aktif obat-obatan. Fraksi etanol 96\% berdasarkan skrining fitokimia dilaporkan mengandung alkaloid, terpenoid, dan tanin yang bersifat antifungal. Fraksi etanol serai merah dilaporkan positif mengandung metabolit sekunder saponin, tanin, kuinon dan steroid serta fraksi metanol serai juga dilaporkan mengandung senyawa saponin, tanin, triterpenoid (Saragih, 2016; Afrina, Nasution and Rahmania, 2018; Utami, 2018)

Penetapan kadar flavonoid total pada ekstrak daun serai telah dilakukan dan dilaporkan rata-rata kandungan flavonoid total yakni $0,02866 \mathrm{~g}$ QE/100 g ekstrak dengan kadar flavonoid 2,866\%. Skrining kandungan kimia minyak atsiri daun serai berdasarkan metode GC-MS telah dilaporkan dan terdapat 34 kandungan kimia. Hasil interpretasi yang diidentifikasi sebanyak 8 senyawa berdasarkan Standart Library Whilley dan NIST (>1\%) yaitu 2,4pentanediol, $\alpha$-Pinen, 2- $\beta$-Pinene, Delta 3Carene, 1-Limonene, Citronella, $\beta$ Citronellol, dan Geraniol. Beberapa senyawa kimia seperti $\alpha$-Pinen, Geraniol, dan 1-Limonene diduga dapat berpotensi sebagai antikanker dan senyawa citronella berpotensi sebagai agent repellent sehingga dapat digunakan untuk menghalau serangga (Nura, 2017; Nuryadin et al., 2018).

\section{Formulasi dan Pengujian Aktifitas Tablet Antifeedant}

Minyak atsiri daun jeruk purut dan serai telah diformulasikan dalam bentuk sediaan tablet untuk mengetahui efektivitas minyak atsiri daun jeruk purut dan serai sebagai repellent terhadap hama kutu beras (S. oryzae). Konsentrasi minyak atsiri daun jeruk purut yang diaplikasikan ialah $4 \mathrm{ml} / \mathrm{g}$, $8 \mathrm{ml} / \mathrm{g}, 12 \mathrm{ml} / \mathrm{g}$, dan $16 \mathrm{ml} / \mathrm{g}$ berpengaruh nyata terhadap jumlah $S$. oryzae yang hadir. Pemberian minyak atsiri daun jeruk purut dengan perlakuan $16 \mathrm{ml} / \mathrm{g}$ menghasilkan imago $S$. oryzae lebih sedikit dibandingkan perlakuan $4 \mathrm{ml} / \mathrm{g}, 8 \mathrm{ml} / \mathrm{g}$, dan $12 \mathrm{ml} / \mathrm{g}$. Hal ini dilihat dari jumlah imago $S$. oryzae pada perlakuan $8 \mathrm{ml} / \mathrm{g}$ yaitu sebanyak 0,67 ekor (Yanuarty, 2021).

Minyak atsiri daun jeruk purut memberikan Indeks Repellent pada saat rentang waktu 3 jam. Penggunaan minyak atsiri daun jeruk purut pada saat rentang waktu 24 jam menghasilkan penurunan Indeks Repellent dan semakin tinggi konsenterasi minyak atsiri daun jeruk purut pada tablet maka jumlah $S$. oryzae dewasa keturunan pertama semakin sedikit (Fajarwati, Himawan and Astuti, 2015).

Daun serai yang diformulasikan dalam bentuk serbuk juga telah dilakukan pengujian mortalitas terhadap $S$. oryzae. Penelitian yang dilakukan untuk melihat kemampuan dan keefektifan insektisida nabati dalam membunuh kutu beras dengan pengamatan selama 7,14 , dan 21 hari. Pengamatan hari ke 7, 14, dan 21 diperoleh persentasi mortalitas $S$. oryzae untuk daun serai yakni $21 \%, 22 \%$, dan $23 \%$. Dengan demikian, dapat diketahui bahwa daun serai efektif untuk membunuh $S$. oryzae dengan jumnlah persentasi mortalitas $66 \%$. Insektisida nabati memiliki kemampuan terhadap mortalitas kutu beras dan efektif jika jumlah total persentase mortalitas sama atau melebihi 50\% (Isnaini, Pane and Wiridianti, 2015).

Insektisida nabati lainnya juga telah diformulasikan menjadi tablet antifeedant yaitu minyak mimba. Minyak mimba digunakan sebagai zat aktif kemudian diemulsikan menggunakan tween 80 dan dicampur dengan talk kemudian dicetak menggunakan alat cetak tablet. Diperoleh mortalitas imago $R$. dominica akibat aplikasi fumigan tablet berbasis minyak mimba sebesar $97,92 \%$ dengan waktu yang dibutuhkan fumigan tablet berbasis minyak mimba untuk mematikan imago $R$. dominica sebanyak $50 \%$ adalah 75,4 jam (Damayanti, Himawan and Astuti, 2013). 
Kandungan minyak atsiri pada daun jeruk serta daun serai dimanfaatkan sebagai antifeedant yang dapat membuat nafsu makan serangga berkurang. Minyak atsiri juga bersifat toksik karena mengandung gugus fungsi hidroksil $(-\mathrm{OH})$ dan karbonil. Senyawa tersebut akan mendenaturasi dan menginaktifkan protein seperti enzim. Oleh karena itu, dinding sel akan mengalami kerusakan, terganggunya transport ion-ion organik penting yang akan masuk, mempengaruhi mekanisme tubuh larva yang pada akhirnya dapat menyebabkan kematian (Nura, 2017). Untuk memudahkan penggunaan kandungan minyak atsiri pada daun jeruk serta daun serai, maka dibuat sediaan insektisida nabati salah satunya, dalam bentuk tablet.

Efek antifeedant insektisida nabati dari minyak jeruk yakni memiliki aktivitas penolak rayap tanah (Coptotermes sp.) paling tinggi pada konsentrasi $20 \%$ dan $25 \%$ dalam waktu uji selama kurang dari 5 hari. Hal ini dikarenakan adanya kandungan sitronelal yang terdapat di dalam minyak atsiri kulit jeruk (C. hystrix) sebesar 14,18\% (Noverita, Jayuska and Alimuddin, 2014). Insektida nabati minyak serai dapat mengendalikan beberapa hama, diantaranya (Helicoverpa armigera) lalat buah (Istianto, 2009), hama penghisap buah lada, Dasynus piperis (Laba, 2016), hama penghisap buah kakao, Helopeltis antonii (Nurmansyah, 2016), hama penggerek buah mangga, Noorda albizonalis dan Plutella xylostella (Zahro, Himawan and Mudjiono, 2016). Penelitian (Kongkaew et al., 2011) minyak serai juga bersifat repellent terhadap nyamuk Aedes, (Anopheles dan Culex).

Insektisida nabati minyak serai memiliki pengaruh terhadap kematian serangga $S$. oryzae dengan rata-rata tertinggi, yakni 4,2 selama pengamatan seminggu diikuti oleh minyak daun jeruk dengan rata-rata 3,2 dan selama 2 minggu mengalami kenaikan dua kali lipat. Ratarata persentase kematian Artemia salina mencapai $50 \%$ pada konsentrasi minyak atsiri serai $500 \mu \mathrm{g} / \mathrm{ml}$ dengan nilai $\mathrm{LC}_{50}$ sebesar $323.59 \mu \mathrm{g} / \mathrm{ml}$. Dengan demikian minyak atsiri serai diduga mempunyai potensi toksisitas terhadap larva dan kandidat obat anti kanker (Nura, 2017). Daun pepaya yang disemprot dengan minyak serai dengan konsentrasi $0,5 \mathrm{~mL} / \mathrm{L}$ dan $1 \mathrm{~mL} / \mathrm{L}$ sama sekali tidak disukai oleh kutu putih pada 1 jam pertama. Daun tersebut baru mulai disukai 1-2 ekor kutu putih setelah 2-4 jam. Sementara itu, daun pepaya yang diaplikasikan dengan minyak serai dengan konsentrasi $2 \mathrm{~mL} / \mathrm{L}$ sama sekali tidak disukai oleh kutu putih sejak awal sampai 4 jam setelah aplikasi. minyak serai sebanyak $2 \mathrm{~mL} / \mathrm{L}$ memberikan persentasi repelensi mencapai $97 \%$ (Octriana and Istianto, 2021).

\section{Kesimpulan}

Berdasarkan uraian studi literatur diatas dapat disimpulkan bahwa daun jeruk purut dan daun serai memiliki banyak senyawa kimia yang bermanfaat sebagai agent repellent. Berdasarkan skrining senyawa kimia, daun jeruk purut dan serai mengandung senyawa citronella dan geraniol yang berfungsi sebagai senyawa antifeedant sehingga dapat digunakan sebagai insektisida nabati untuk berbagai hama termasuk kutu beras. Minyak atsiri daun jeruk purut dan serai juga telah berhasil diformulasikan menjadi sedian farmasi yakni tablet antifeedant dan terbukti memiliki efek membunuh kutu beras dengan efektivitas diatas 50\% berdasarkan uji mortalitas kutu beras.

\section{Daftar Pustaka}

Afrina, Nasution, A. I. and Rahmania, N. 2018. Konsentrasi Hambat Dan Bunuh Minimum Ekstrak Serai (Cymbopogon Citratus) Terhadap Candida Albicans. Cakradonya Dental Journal, 9(1), Pp. 55-61.

Badan Pusat Statistik. 2020. Luas Panen Dan Produksi Padi Di Indonesia 2019. Badan Pusat Statistik Indonesia.

Baheramsyah. 2021. Indonesia Peringkat Ketiga Penghasil Beras Terbesar Di Dunia, Infopublik. URL:https://infopublik.id/kategori/na sional-ekonomibisnis/521429/indonesia-peringkatketiga-penghasil-beras-terbesar-didunia.

Damayanti, R. R., Himawan, T. dan Astuti, 
L. P. 2013 Penghambatan Reproduksi Rhyzopertha Dominica F. (Coleoptera: Bostrichidae) Menggunakan Fumigan Tablet Berbasis Minyak Mimba. 1(September), Pp. 17-26.

Fajarwati, D., Himawan, T. dan Astuti, L. P. 2015. Uji Repelensi Dari Ekstrak Daun Jeruk Purut (Cytrus Hystrix) Terhadap Hama Beras Sitophilus Oryzae Linnaeus (Coleoptera: Curculionidae). Jurnal Htp, 3(1), Pp. 102-108.

Ginting, B. 2012. Antifungal Activity Of Essential Oils Some Plants In Aceh Province Against Candida Albican. Jurnal Natural Unsyiah. 12(2), P. 115218.

Hanina, H. dan Baringbing, S. M. 2020. Efektivitas Ekstrak Daun Jeruk Purut (Citrus Hystrix) Sebagai Insektisida Alami Terhadap Kecoak Amerika (Periplaneta Americana) Dengan Metode Semprot. Jambi Medical Journal 'Jurnal Kedokteran Dan Kesehatan'. 8(1), Pp. 8-14.

Isnaini, M., Pane, E. R. dan Wiridianti, S. 2015. Pengujian Beberapa Jenis Insektisida Nabati Terhadap Kutu Beras (Sitophilus Oryzae L). Jurnal Biota, 1(1). Pp. 1-8.

Istianto. 2009. Pemanfaatan Minyak Atsiri, Alternatif Teknologi Pengendalian Organisme Pengganggu Tanaman Buah. Iptek Hortikultura. (5). Pp. 3438.

Kongkaew, C. Sakunrag, I. Chaiyakunapruk, S. dan Tawatsin, A. 2011. Effectiveness Of Citronella Preparations In Preventing Mosquito Bites: Systematic Review Of Controlled Laboratory Experimental Studies. Tropical Medicine And International Health. 16(7), Pp. 802810.

Laba, I. W. 2016. Efektivitas Insektisida Minyak Serai Wangi Dan Cengkeh Terhadap Hama Pengisap Buah Lada (Dasynus Piperis China). Buletin Penelitian Tanaman Rempah Dan Obat, 24(1). Pp. 26-34.

Lestari, N. 2020. Uji Beberapa Konsentrasi
Tepung Daun Serai (Cymbopogon Citratus (Dc.) Stapf.) Terhadap Mortalitas Hama Kutu Beras (Sitophilus Oryzae L.). [Skripsi]. Fakultas Pertanian dan Peternakan UIN SUSKA. Riau.

Lestari, S., Jayuska, A. dan Indrayani, Y. 2015. Bioaktivitas Minyak Atsiri Daun Jeruk Purut (Citrus Hystrix) Terhadap Rayap Tanah (Coptotermes Sp.). Jkk, 4(4), Pp. 83-88.

Noverita, Jayuska, A. dan Alimuddin, A. H. 2014. Uji Aktivitas Antirayap Minyak Atsiri Kulit Jeruk Purut (Cytrus Hystric D.C). Jurnal Kimia Khatulistiwa, 3(2), Pp. 19-22.

Nura, A. 2017. Uji Toksisitas Minyak Atsiri Serai Wangi (Cymbopogon Nardus L. Rendle) dengan Metode Brine Shrimp Lethality Test (Bslt). [Skripsi] Pp. 737. FMIPA USU. Medan.

Nurmansyah, N. 2016. Pengaruh Interval Aplikasi Dan Waktu Penyemprotan Pestisida Nabati Seraiwangi Terhadap Hama Helopeltis Antonii Pada Tanaman Kakao. Buletin Penelitian Tanaman Rempah Dan Obat, 25(1), P. 53.

Nuryadin, Y. Naid, T. Dahlia, S. dan Dali, S. 2018. Kadar Flavonoid Total Ekstrak Etanol Daun Serai Dapur Dan Daun Alang-Alang Menggunakan Spektrofotometri UV-VIS. Jurnal Kesehatan, 1(4), Pp. 337-345.

Octriana, L. dan Istianto, M. 2021. Efektivitas Minyak Sereh Wangi Dalam Mengendalikan Kutu Putih Pepaya Paracoccus Marginatus L. Jurnal Budidaya Pertanian, 17(1), Pp. 15-22. Doi: 10.30598/Jbdp.2021.17.1.15.

Putri, E. S. 2017. Efektivitas Daun Citrus Hystrix Dan Daun Syzygium Polyanthum Sebagai Zat Penolak Alami Periplaneta Americana. Universitas Negeri Semarang, 1(1), Pp. 1-7.

Sakul, E. H. Manoppo, S Taroreh, D. Gerungan, R. dan Gugule, S. 2012. Pengendalian Hama Kumbang Logong (Sitophylus Oryzae L.) Dengan Menggunakan Ekstrak Biji 
Pangi (Pangium Edule Reinw.).

Eugenia, 18(3).

Santya, R. N. R. E. dan Hendri, J. 2013. Daya Protekasi Ekstrak Kulit Jeruk Purut (Citrus Hystrix) Terhadap Nyamuk Demam Berdarah. Aspirator, 5(2)(2), Pp. 41-44.

Saragih, F. M. 2016. Ekstrak Minyak Atsiri Serai [Cymbopogon Citratus (Dc.) Stapf] Sebagai Anti Bakteri Dalam Hand Sanitizer. Journal Universitas Atma Jaya, Pp. 1-36.

Soenandar, M., Aeni, M. And Raharjo, A. 2010. Petunjuk Praktis Membuat Pestisida Organik'. Agromedia Pustaka.

Utami, T. S. R. 2018. Uji Efektivitas Ekstrak Etanol ( Cymbopogon Nardus ( L ) Rendle ) Dalam Membasmi Larva Aedes Aegypti.

Yanuarty, R. 2021. Uji Aktivitas Antioksidan Daun Jeruk Nipis (Citrus Aurantifolia) Secara Spektrofotometri Uv-Vis. Jurnal Farmasindo Politeknik Indonusa Surakarta, Vol. 5, Pp. 53-56.

Zahro, F. A., Himawan, T. dan Mudjiono, G. 2016. Uji Bioaktivitas Ekstrak Daun Serai Wangi (Cymbopogon Nardus L. Rendle) Terhadap Plutella Xylostella Linnaeus. Jurnal Hpt, 4(2), Pp. 85-92. 